\title{
ПЕРСПЕКТИВИ ЗАСТОСУВАННЯ НОВИХ ПІДХОДІВ ДО ВПРОВАДЖЕННЯ МАТЕМАТИЧНИХ ТЕХНОЛОГІЙ ДЛЯ ВИВЧЕННЯ ДІЯЛЬНОСТІ КЛІТИНИ
}

\author{
Львівський медичний інститут
}

\begin{abstract}
Вивченню підлягають фотографії ультратонких зрізів досліджуваних біологічних тканин. Відповідно до методу визначення профілів спеціальних можливостей гормонопоетичних клітин, який ґрунтується на даних цитосрізіології щодо фрункціонального значення окремих органел, та використовуючи елементи кластерного аналізу, органели поділяють на окремі групи (кластери) згідно з їх спеціалізацією в клітині. Застосовуючи принцип методу фазового інтервалу, будову і стан складових елементів кожного кластеру порівнюють 3 такими в аналогічних ультраструктурах у нормі і при досліджуваних відхиленнях від неї. Використовуючи метод напівкількісного аналізу електронограм, за шкалою градацій здійснюють цифрове оцінювання ступеня вираженості ознак у кожного елемента кластеру. Усереднені результати оцінювання складових елементів кластеру є підставою для встановлення певних взаємозалежностей між ними, які об'єктивізують шляхом кореляційного аналізу з побудовою внутрішньокластерних (внутрішньосистемних) кореляційних портретів. Як приклад наводиться порівняльне дослідження синтетичної спроможності фолікулярних тироцитів щитоподібної залози щурів, здійснене засобами загальновживаного лінгвістичного опису та аналізу побудованого кореляційного портрета.

Запропонований підхід до вивчення гормонопоетічної клітини дозволяє встановлювати взаємозв'язки між органелами не тільки в межах певного кластеру і констатувати особливості реалізації певного напряму діяльності, а й проводити пошук потенційних і резервних можливостей клітини, істотно розширює уявлення про її фуннціональні можливості як базову основу життєдіяльності будь-якого біологічного об'єкта.
\end{abstract}

Ключові слова: математичні технології, клітина, щитоподібна залоза, фолікулярний тироцит.

\section{PERSPECTIVES OF APPLYING NEW APPROACHES TO THE IMPLEMENTATION OF MATHEMATICAL TECHNOLOGIES IN THE STUDY OF CELL ACTIVITY}

O. I. Ryabukha

\section{Lviv Medical Institute}

Photographs of ultrathin sections of the studied tissues are subject to the research. According to the method of determining the profiles of specific capabilities of hormonopoietic cells, based on cytophysiology data on the functional values of individual organelles and using elements of the cluster analysis, organelles are divided into separate groups (clusters) in accordance with their specialization in the cell. While applying the method of semi-quantitative analysis of electronograms, the structure and condition of the constituent elements of each cluster are compared with those in analogous ultrastructures both in the normal range and in the studied deviations. While applying the method of semi-quantitative analysis of electronograms, grading scale performs a digital evaluation of the characteristics' severity of each cluster element. The averaged results of the cluster elements evaluation serve as the basis for establishing certain interdependencies between them, which are objectified by correlation analysis with the construction of intra-cluster (intra-system) correlation portraits. For instance, a comparative study of the synthetic capacity of follicular thyrocytes in the thyroid gland of rats is presented through the commonly used linguistic description and analysis of the constructed correlation portrait.

Suggested approach to the study of a hormonopoietic cell not only makes it possible to establish interconnections between organelles within a certain cluster and to note the peculiarities of the implementation of a certain activity direction, but also allows to search for potential and reserve capabilities of the cell, which, in its turn, significantly broadens the very idea of its functional capabilities as the basis of life of any biological object.

Key words: mathematical technologies, cell, thyroid gland, follicular thyrocyte. 


\title{
ПЕРСПЕКТИВЫ ПРИМЕНЕНИЯ НОВЫХ ПОДХОДОВ К ВНЕДРЕНИЮ МАТЕМАТИЧЕСКИХ ТЕХНОЛОГИЙ ДЛЯ ИЗУЧЕНИЯ ДЕЯТЕЛЬНОСТИ КЛЕТКИ
}

О. И. Рябуха

\section{Львовский медицинский институт}

\begin{abstract}
Изучению подлежат фротографрии ультратонких срезов исследуемых биологических тканей. В соответствии с методом определения профилей специальных возможностей гормонопоэтических клеток, основанным на данных цитофизиологии о фрункциональном значении отдельных органелл, и используя элементы кластерного анализа, органеллы разделяют на отдельные группы (кластеры) по их специализации в клетке. Применяя принцип метода фразового интервала, строение и состояние составляющих элементов каждого кластера сравнивают с таковыми у аналогичных ультраструктур в норме и при исследуемых отклонениях от неё. Используя метод полуколичественного анализа электронограмм, по шкале градаций осуществляют цисрровое оценивание степени выраженности признаков у каждого элемента кластера. Усреднённые результаты оценивания составляющих элементов кластера являются основанием для установления определенных взаимозависимостей между ними, которые объективизируют путём корреляционного анализа с построением внутрикластерных (внутрисистемных) корреляционных портретов. В качестве примера приводится сравнительное исследование синтетической способности фролликулярных тироцитов щитовидной железы крыс, произведённое средствами общеупотребительного лингвистического описания и анализа построенного корреляционного портрета.

Предложенный подход к изучению гормонопоэтической клетки позволяет устанавливать взаимосвязи между органеллами не только в пределах определенного кластера и констатировать особенности реализации определенного направления деятельности, но и проводить поиск потенциальных и резервных возможностей клетки, существенно расширяет представления о её фрункциональных возможностях как базовой основы жизнедеятельности любого биологического объекта.
\end{abstract}

Ключевые слова: математические технологии, клетка, щитовидная железа, фолликулярный тироцит.

Вступ. Впровадження математичних технологій у процес дослідження біологічних об'єктів, зокрема людського організму, набуває значного поширення [2, 3, 7, 16]. Нині медична наука потребує оновлення та збагачення арсеналу методів, якими вона послуговується: попри можливості, що відкриває використання сучасної діагностичної апаратури, засадничі підходи до досліджень значною мірою продовжують залишатися емпіричними. Вивчення стану та діяльності будь-якої біологічної системи, зокрема і клітини, відбувається переважно шляхом удосконалення вже існуючих діагностичних напрямків або методик дослідження [1]. Водночас встановлення закономірностей діяльності такої надскладної негентропійної біологічної системи, якою $є$ клітина людського організму, потребує створення нових концепцій дослідження, зокрема розробки та впровадження сучасних експертних систем оцінювання змін іiї стану при впливові різних чинників [18].

Постановка проблеми. Запропоновану концепцію дослідження клітини доцільно базувати на кібернетичних уявленнях про клітину як саморегулювальну систему. У такому випадку клітина будь-якого органу зазнає цілого масиву різноманітних впливів, які можна умовно поділити на такі основні групи: 1 - зовнішні впливи, 2 - внутрішні впливи, зокрема впливи різних систем організму, 3 впливи інших клітин того самого органу. При дії на клітину впливи можуть: а) взаємопідсилюватися, б) взаємоослаблюватися, в) реалізуватися незалежно та ізольовано один від одного. Важливою точкою прикладання їхньої дії в клітині є клітинні ультраструктури, що за сучасними уявленнями суворо спеціалізовані функціонально та реалізують тільки певний конкретний напрям діяльності клітини [4].

Зазнавши відповідних морфологічних змін, зумовлених природою та силою діючого впливу, клітинні ультраструктури змінюють свою активність. Це дозволяє визначати функціональну спроможність органели, аналізуючи ії морфологічний стан. Оскільки клітина є полікомпонентною системою, той самий напрям її діяльності можуть реалізовувати кілька ультраструктур, причому впливи різної природи і сили можуть торкатися їх різною мірою. Логічно припустити, що результати дії чинників (які при різній природі чи силі мають однаковий напрям впливу), будучи скерованими на різні ультраструктури того самого напряму (кластеру), можуть мати певні відмінності.

Матеріали та методи дослідження. Вивченню підлягали електронограми ультратонких зрізів досліджуваної біологічної тканини, що виготовляють 
за загальноприйнятими методиками. Основні методи дослідження:

1. Напівкількісний аналіз електронограм [5]. Аналіз електронограм проводять відповідно до визначеного алгоритму. Оцінювання ступеня вираженості ознак здійснюють за допомогою графічних символів або бальної / відсоткової шкали (табл. 1). Відсутність ознаки оцінюють як 0 балів, незначну вираженість — як 1-2 бали, помірну - як 3 бали, нормальному значенню відповідає оцінка 4 бали. Збільшення кількості ультраструктур запропоновано оцінювати пропорційно до ступеня його вираженості в межах від 4 до 8 балів. Надалі отримані цифрові величини використовували для математичного оброблення.

2. Математична статистика [14]. Цифрові значення результатів досліджень обробляли з визначенням - середнього арифметичного показника та m - стандартної похибки середнього арифметичного показника, що розраховували за загальновживаними формулами. Результати представлено у вигляді симетричного довірчого інтервалу $\pm \mathrm{m}$.

3. Метод фазового інтервалу [8]. Відповідно до засадничих положень цього методу визначення фактичної належності біологічного об’єкту до того чи іншого стану, в якому може перебувати біологічна система, можливе через обчислення віддалі між двома точками у фазовому просторі. У такому випадку розглядається евклідів простір, кожна координата якого відповідає одному з параметрів стану досліджуваного біологічного об’ єкту, тоді як кожна точка фазового простору відповідає його певному стану.

Ідентифікація фактичного стану досліджуваної системи відбувалася через співставлення їі параметрів $з$ показниками двох діаметрально протилежних контролів, що можна позначити як норму та певну хворобу, яка підлягає вивченню / коригуванню.

4. Кореляційний аналіз [14]. Метод кореляційного аналізу застосовують для встановлення наявності взаємозв’ язків між досліджуваними елементами системи та вивчення їх характеру. Клітину вважають складною негентропійною системою, підсистемою якої є певний досліджуваний напрямок її діяльності. Для 3’ясування наявності зв'язків між складовими елементами та характеристики їхньої сили та напряму визначають коефіцієнти парної кореляції, що розраховують за формулою Пірсона.

Позитивне значення коефіцієнта парної кореляції свідчить про однаковий напрям змін досліджуваного показника, негативне - про те, що зі збільшенням одного з показників пов'язаний із ним інший показник зменшується; значення rxy=1,0 вказує на існування прямо пропорційного зв’язку між показниками $\mathrm{x}$ та y, rxy=-1,0 - обернено пропорційного. У структурній організації взаємовідношень між показниками найбільш значущими вважають дуже міцні та міцні зв’язки, що за шкалою кореляції Чеддока перебувають відповідно в межах $1,0 \geq \mathbf{r x y}>0,9$ та $0,9 \geq 0,7$; у разі відсутності таких зв'язків враховують помітні зв'язки $0,7 \geq \mathrm{rxy}>0,5$ та помірні зв'язки $(0,5 \geq \operatorname{rxy}>0,3)$.

5. Метод визначення профілів спеціальних можливостей гормонопоетичних клітин $[6,11]$. Якщо певний напрям діяльності гормонопоетичної клітини (синтез, секреція, транспортування виробленого гормонального продукту по інтраорганному мікрокапілярному руслу, енергетичне забезпечення цих процесів) кваліфікувати як «можливість», то наслідком такої квантифікації є створення профілів відповідних можливостей, реалізація яких забезпечується певними ультраструктурними елементами.

Для аналізу діяльності профілю певної спеціальної можливості всім ознакам кожного ультраструктурного елементу профілю присвоюють відповідний символ з подальшим оцінюванням у цифровому еквіваленті відповідно до рекомендацій методу напівкількісного аналізу електронограм. Метод може бути адаптованим для дослідження діяльності також і клітин негормонального ряду.

Результати та їх обговорення. Для поглибленого дослідження певного напряму діяльності клітини, кваліфікованого нами як можливість, визначали окремі сукупності клітинних ультраструктурних елементів, що його реалізують. Таким чином, відбувається формування кластеру — профілю певної можливості.

Ступінь проявів кожної ознаки клітинних ультраструктур досліджуваної можливості визначають порівнянням їх з такими в двох еталонах, якими $\epsilon$ зрізи досліджуваної тканини в нормі та при певній нелікованій патології. Цифрове оцінювання стану ультраструктурних елементів профілю 
здійснювали за розробленою нами цифровою шкалою (табл. 1).

Таблиця 1

\section{Шкала оцінювання вираженості ознак при напівкількісному аналізі електронограм}

\begin{tabular}{|c|c|c|c|}
\hline Ступінь вираже- & Графічний & \multicolumn{2}{|c|}{ Цифрова оцінка } \\
\cline { 3 - 4 } ності ознаки & символ & бали & $\%$ \\
\hline Відсутній & - & 0 & 0 \\
\hline Слабкий & + & 1 & 25 \\
\hline Помірний & ++ & 2 & 50 \\
\hline Значний & +++ & 3 & 75 \\
\hline $\begin{array}{c}\text { Дуже значний } \\
\text { (максимальний) }\end{array}$ & ++++ & 4 & 100 \\
\hline
\end{tabular}

Отримані цифрові дані підлягають подальшому усередненню та кореляційному аналізу. При такому підході об'єктом дослідження є клітина, а його предметом - зміни ії морфофункціонального стану при різних впливах [17]. На підставі отриманих даних у межах досліджуваного профілю здійснюють побудову внутрішньосистемних кореляційних портретів, які є графічним відображенням встановлених кореляційних зв’язків. Аналіз кореляційних портретів передбачає інтерпретацію отриманих відомостей про морфофункціональний стан кожної з досліджуваних ультраструктур кластеру та зв'язки між ними, узагальнену характеристику портрета як цілісної структури, встановлення наближеності портрета до характеристик стану норми чи певної досліджуваної патології. Використання кореляційних портретів дає змогу порівнювати наслідки різних впливів на основоположні аспекти діяльності клітини. Інтерпретуючи дані, отримані під час аналізу кореляційних портретів, ми спираємося на загальні поняття про біологічні системи та підходи до їх вивчення в нормі і патології, відповідно до яких будьяка система характеризується властивостями своїх елементів і ступенем їх проявів та типом і щільністю зв'язків між елементами системи [1].

Понятійний апарат дослідження внутрішньосистемних кореляційних портретів профілів можливостей передбачає теоретичне визначення функціонально значимих для реалізації досліджуваного напрямку «опорних» ознак, які є спільними для всіх кореляційних портретів профілю досліджуваної можливості, практичне встановлення «фактичних» ознак, які є індивідуальними для кожного кореляційного портрета, «вузлових точок» як скупчень кореляційних зв’ язків, що притаманні певному кореляційному портрету. Це дає змогу узагальнювати, індивідуалізовувати дослідження та розширювати ареал пошуку тих закономірностей у діяльності клітини, на які вказують взаємозв'язки і взаємозумовленості між складовими елементами кожного досліджуваного профілю.

Інформативність запропонованого нами математичного підходу до вивчення клітини та перспективи його використання унаочнюємо прикладом дослідження базового елемента щитоподібної залози — фолікулярного тироцита. Синтетичні можливості фолікулярних тироцитів білих безпородних щурів-самців досліджено в модельних умовах функціонального гіпертиреозу, викликаного пероральним прийманням тиреоїдину, із застосуванням традиційного вивчення електронограм шляхом лінгвістичного опису та запропонованого нами підходу з аналізом побудованого внутрішньосистемного кореляційного портрета профілю синтетичних можливостей (табл. 2, рис. 1, 2).

Відповідно до даних лінгвістичного опису візуальний аналіз особливостей ультраструктурних складових профілю синтетичних можливостей фолікулярних тироцитів дав змогу встановити, що в цитоплазмі клітин був суттєво зменшений загальний вміст елементів гранулярного ретикулуму; кількість рибосом на його мембранах була зменшеною. Вміст вільних рибосом і полісом у цитоплазмі був значно зменшеним. Комплекс Гольджі був сформований з плоских ламел та порожнин. Електронна щільність цитоплазми тироцитів була помірно збільшеною. Описана картина може свідчити про значні утруднення при здійсненні інтратироцитарних процесів білкового синтезу та вироблення специфічного гормонального продукту.

Дослідження кореляційного портрета показало, що фактичними ознаками стану ультраструктурних елементів тироцитів, які були задіяні у його побудові, були В1, J2, J3, J4, J5, K1, K2, L1, L2, L3; вузловими точками портрета були J2, J5, K1, K2, L3. Усього простежено 20 кореляційних зв'язків: дуже міцні $(1,0 \geq|r|>0,9)-7$ ( 3 них 2 непрямі); міцні - 0 ; помітні $(0,7 \geq|r| \geq 0,5)-13$ (з них 6 непрямих). Загалом архітектоніка портрета характеризувалася стійкістю та ригідністю; певну здатність до змін їй можуть забезпечити 8 непрямих зв’язків.

Аналіз особливостей портрета показав виразну взаємозалежність розширених субструктур гранулярного цитоплазматичного ретикулуму (J3) і зменшеної кількості рибосом на його мембранах (J4) та помірної кількості зв’язаних рибосом (J5) і достатньої кількості вільних рибосом (K2): в обох випадках простежено дуже міцні 
Таблиця 2

Профіль синтетичних можливостей фолікулярних тироцитів

\begin{tabular}{|c|c|c|c|}
\hline $\begin{array}{c}\text { Ультраструктурний } \\
\text { елемент }\end{array}$ & $\begin{array}{c}\text { Досліджувана ознака } \\
\text { ультраструктурного елементу }\end{array}$ & $\begin{array}{c}\text { Якість ознаки до- } \\
\text { сліджуваного ультра- } \\
\text { структурного елементу }\end{array}$ & $\begin{array}{c}\text { Умовна позначка озна- } \\
\text { ки досліджуваного } \\
\text { ультраструктурного } \\
\text { елементу }\end{array}$ \\
\hline \multirow{3}{*}{ Цитоплазма } & \multirow{3}{*}{ Електронна щільність } & Незначна & B1 \\
\hline & & Помірна & B2 \\
\hline & & Значна & B3 \\
\hline \multirow{6}{*}{$\begin{array}{c}\text { Гранулярний } \\
\text { цитоплазматичний } \\
\text { ретикулум }\end{array}$} & \multirow{3}{*}{ Будова складових елементів } & Звужена & $\mathrm{J} 1$ \\
\hline & & Нормальна & $\mathrm{J} 2$ \\
\hline & & Розширена & J3 \\
\hline & \multirow{3}{*}{$\begin{array}{c}\text { Кількість рибосом на мемб- } \\
\text { ранах }\end{array}$} & Незначна & $\mathrm{J} 4$ \\
\hline & & Помірна & J5 \\
\hline & & Збільшена & J6 \\
\hline \multirow{3}{*}{$\begin{array}{c}\text { Вільні рибосоми та по- } \\
\text { лісоми }\end{array}$} & \multirow{3}{*}{ Кількість } & Незначна & K1 \\
\hline & & Помірна & K2 \\
\hline & & Значна & K3 \\
\hline \multirow{3}{*}{ Комплекс Гольджі } & \multirow{3}{*}{ Будова складових елементів } & Звужена & L1 \\
\hline & & Нормальна & L2 \\
\hline & & Розширена & L3 \\
\hline
\end{tabular}

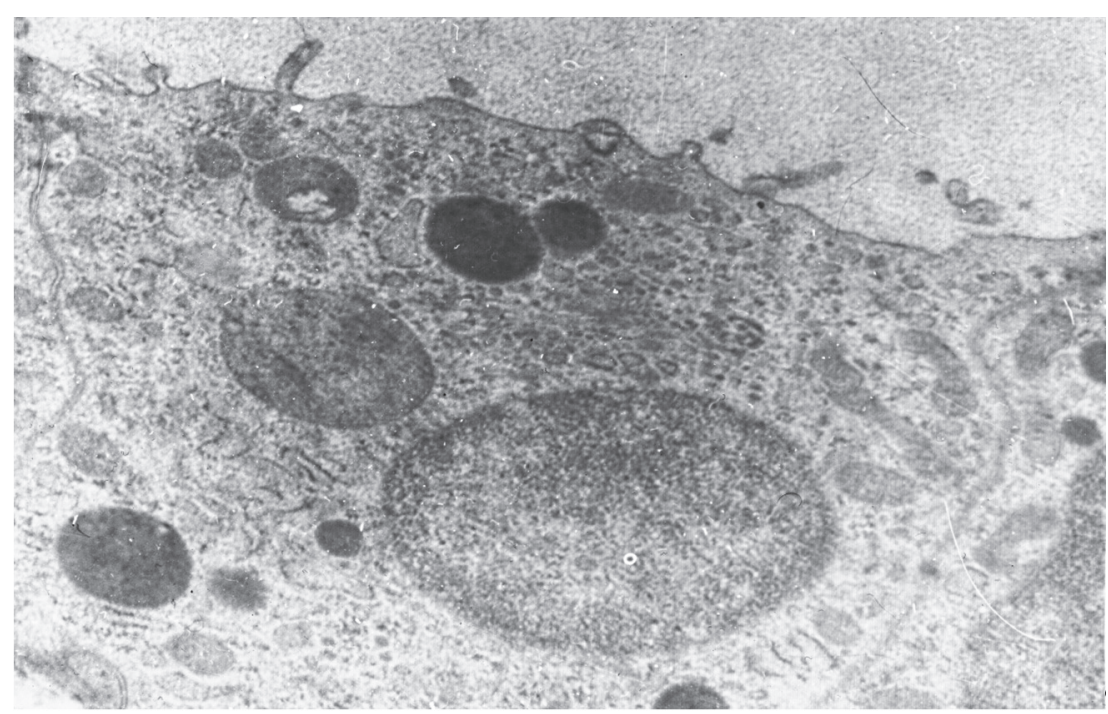

Рис. 1. Фолікулярний тироцит щитоподібної залози щура в модельних умовах функціонального гіпертиреозу 6000 


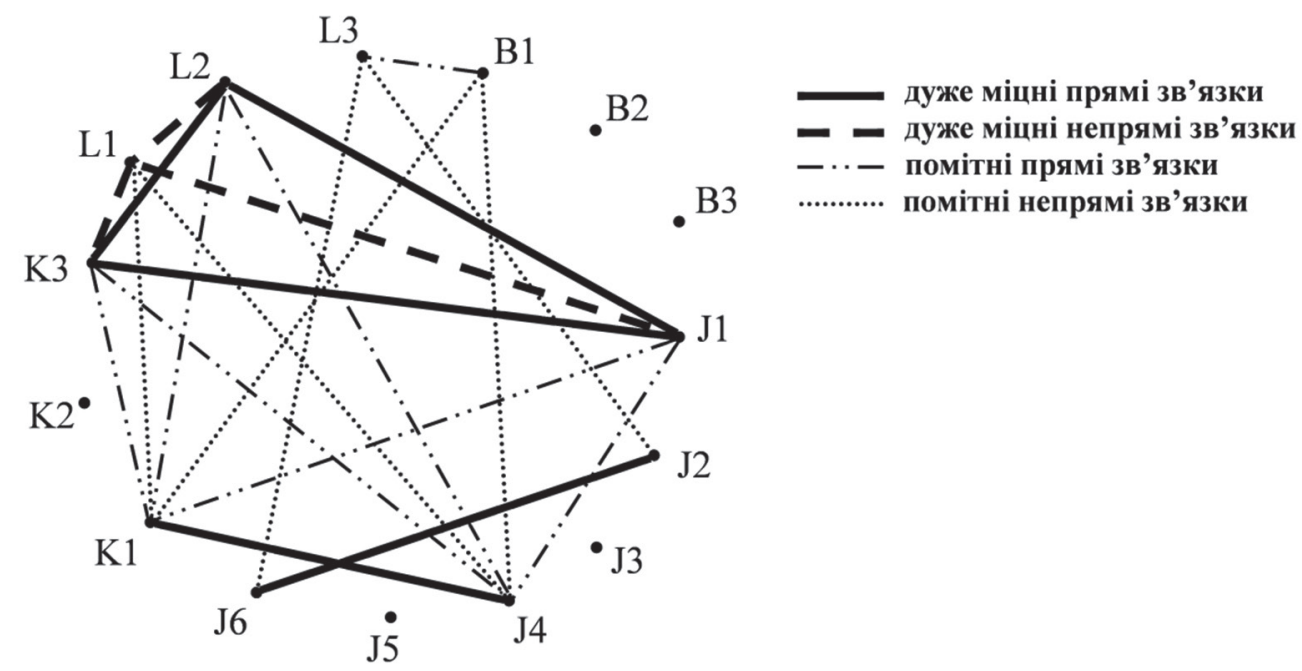

Рис. 2. Графичне зображення кореляційного портрета профілю синтетичних можливостей фолікулярних тироцитів щитоподібних залоз щурів у модельних умовах функціонального гіпертиреозу

кореляційні зв’язки. Помірно виражені субструктури гранулярного цитоплазматичного ретикулуму (J2) були дуже міцно пов'язані зі зменшеною кількістю вільних рибосом (K1) і розширеними субструктурами комплексу Гольджі (L3). Останні (розширені субструктури комплексу Гольджі) також були дуже міцно пов'язані зі зменшеною кількістю зв'язаних рибосом (K1). На нашу думку, такі особливості внутрішньоклітинних зв'язків можуть бути проявом не тільки порушення синтетичної спроможності тироцита, але і його пристосування до функціонування в умовах гіпертиреозу. Наявна дисоціація між станами основних протеїносинтезувальних ультраструктур, яка полягала в дуже міцному непрямому зв’язку між нормальними будовами субструктур гранулярного цитоплазматичного ретикулуму (J2) та комплексу Гольджі (L2), підтверджує різницю в їх ролях у процесі гормонопоезу. Дуже міцний непрямий зв’язок зменшеної кількості вільних рибосом (K1) та нормальної будови субструктур комплексу Гольджі (L2) не тільки свідчить про велике значення цих ультраструктур для нормального перебігу процесів білкового синтезу, але і вказує на наявність порушення гормонопоезу.

В обговорюваному кореляційному портреті профілю синтетичної можливості фолікулярних тироцитів привертає увагу відсутність міцних зв'язків. Це зумовило необхідність аналізу зв'язків меншої сили. Із 13 проаналізованих помітних зв'язків найбільша кількість була пов'язана зі зв'язаними та вільними рибосомами. Водночас простежено зв'язки між помірною кількістю зв'язаних рибосом (J5), нормальною будовою субструктур гранулярного цитоплазматичного ретикулуму (J2), розширеними елементами комплексу Гольджі (L3) та зменшеною кількістю вільних рибосом (K1), що можуть підтверджувати як взаємозумовленість дії зв'язаних рибосом та гранулярного цитоплазматичного ретикулуму, так і відмінності щодо функціонального значення вільних і зв'язаних рибосом. Простежені помітні зв'язки достатньої кількості вільних рибосом і полісом (K2) з нормальною будовою субструктур гранулярного цитоплазматичного ретикулуму (J2) та розширеною будовою субструктур комплексу Гольджі, а також зв’язок такої ж сили між зменшеною і достатньою кількістю вільних рибосом (відповідно К1, К2) вказують на наявність утруднень у реалізації синтетичної діяльності тироцита. Це підтверджує і помітний прямий зв’язок, установлений між звуженими субструктурами комплексу Гольджі (L1) і незначною електронною щільністю цитоплазми (В1).

Отже, впровадження математичних технологій у морфологічні дослідження дає змогу суттєво розширити можливості при встановленні як закономірностей, так і особливостей функціонування клітин у нормі та патології. Навіть у несприятливих умовах гормональний синтез $є$ важливим напрямком діяльності тироцита, свідченням чого є значна кількість кореляційних зв’язків між ультраструктурами профілю, що логічно інтерпретувати не тільки як ознаки функціональної активності чи напруження, але і як прояв пристосувальних механізмів, призначених реалізовувати синтетичну діяльність тироцита в умовах, які її порушують. 
Прикладом таких механізмів із забезпечення специфічної діяльності тироцита в умовах підвищеного функціонального напруження ми можемо вважати кореляційні зв'язки між протеїносинтезувальними ультраструктурами з різним ступенем їх функціональної активності [10, 13].

Такий погляд на вивчення гормонопоетичної клітини дає змогу встановлювати взаємозв’язки між органелами не тільки у межах певного кластеру та констатувати особливості реалізації певного напрямку діяльності, але й проводити пошук потенційних і резервних можливостей клітини, що суттєво розширює уявлення щодо їі функціональних можливостей як базисної основи життєдіяльності будь-якого біологічного об’єкту.

\section{Висновки.}

1. Запропонований підхід до цитоморфологічних досліджень можна вважати варіантом гібридної дослідницької системи, оскільки формалізація отриманих відомостей передбачає застосування пакета взаємопов'язаних методів (кластерний і кореляційний аналіз, методи фазового інтервалу і математичної статистики, напівкількісний аналіз електронограм, визначення профілів спеціальних можливостей). Це дає змогу отримані якісні показники (мало більше - багато, вузько - ширше - широко, тощо) трансформувати у кількісні з можливістю подальшого об’єктивізування отриманих результатів. Важливою особливістю запропонованого є відсутність строгої детермінованості, яка не притаманна біологічним об’єктам, що кореспондується із сучасними підходами до створення експертних систем [9, 15, 19].

2. Дослідження особливостей морфофізіології клітини, здійснене з позицій її пріоритетної саморегуляції, при побудові внутрішньосистемних кореляційних портретів дозволяє аналізувати зв'язки між клітинними ультраструктурами (їх наявність, напрямок, силу), що суттєво розширює можливості цитофізіології як науки і поглиблює уявлення про функціонування клітини в різних станах і умовах.

3. Практичне застосування побудови внутрішньосистемних кореляційних портретів, здійснене з позицій уявлень про клітину як складну саморегулювальну систему, в якій точкою прикладання дії різних чинників, що мають однаковий напрям впливу, є різні органели однієї функціональної спеціалізації, дає змогу при подібності кінцевих наслідків впливу встановлювати і аналізувати відмінності і особливості, які виникають у діяльності клітини під впливом різних внутрішніх і зовнішніх чинників.

4. Побудова кореляційних портретів профілів кожної з досліджуваних можливостей та їх подальший аналіз дає змогу простежувати внутрішньосистемні зв’язки між ультраструктурами профілю, які пов’язані спільною діяльністю, при різних станах клітини, що сприяє глибшому дослідженню їх взаємозалежності та більш повній характеристиці у цих напрямках під впливом різних чинників в різних умовах життєдіяльності. У такому випадку кореляційний портрет набуває значення полікомпонентної поліваріантної експертної системи.

5. Запропонований підхід до вивчення діяльності біологічної системи на базовому (органелоклітинному) рівні ії функціонування дає змогу побудови внутрішньосистемних кореляційних портретів профілів можливостей клітин та встановлення міжсистемних зв'язків між профілями різних можливостей, що не тільки об’єктивізує стан досліджуваної клітини на момент її вивчення, але й дає змогу визначати її потенційні і резервні можливості.

\section{Література.}

1. Автандилов Г. Г. Основы количественной патологической анатомии / Г. Г. Автандилов. - М. : АМЛ, 2002. - 240 с.

2. Гублер Е. В. Применение непараметрических критериев статистики в медико-биологических исследованиях / Е. В. Гублер, А. А. Генкин. - Л. : Медицина, 1973. - 143 с.

3. Застосування кореляційного портрету в диференційній діагностиці захворювань серцево-судинної, легеневої та нервової систем / Д. В. Вакуленко, Л. О. Вакуленко, Н. О. Кравець [та ін.] // Медична інформатика та інженерія. — 2017. — № 2. — С. 4-8.

4. Луценко М. Т. Цитофизиология : руководство / М. Т. Луценко. - Новосибирск; Благовещенск : СО РАМН, 2011. - 216 с.

5. Метод напівкількісного аналізу електронограм за Рябухою О. І. : авторське свідоцтво ДААСП України ПА № 2769; зареєстр. 16.02.2000 / О. І. Рябуха // Каталог державної реєстрації. - 2000. — Вип. 4. — С. 11.

6. Метод Рябухи О. І. Визначення профілів спеціальних можливостей гормонпоетичних клітин : авторське свідоцтво ДДІВ України № 7966; зареєстр. 15.07.2003 / О. І. Рябуха // Авторське право і суміжні права. - 2003. - Вип. 4. 3/4 С. 72. 
7. Мінцер О. П. Оброблення клінічних і експериментальних даних у медицині : навч. посіб. для студ. вищ. навч. закл. / О. П. Мінцер, Ю. В. Вороненко, В. В. Власов. - К. : Вища школа, 2003. - 350 с.

8. Основные виды врачебной логики / Е. В. Плащевая, В. А. Смирнов, Н. В. Нигей, В. А. Лысак // Пособие для практических занятий по медицинской информатике : учебное пособие. - Благовещенск : АГМА, 2014. - C. 176.

9. Ротштейн А. П. Медицинская диагностика на нечёткой логике / А. П. Ротштейн. - Винница : Континент-Прим, 1996. - 132 с.

10. Рябуха О. І. Дослідження синтетичної діяльності фолікулярних тироцитів при прийманні неорганічного йоду в умовах аліментарного йододефіциту / О. I. Рябуха // Вісник проблем біології і медицини. 2017. - Вип. 4, Т. 3, № 141. - С. 218-223.

11. Рябуха О. І. Об’єктивізація морфофункціонального стану тироцита шляхом визначення профілів його спеціальних можливостей / О. І. Рябуха // Таврический медико-биологический вестник. — 2006. - Т. 9, № 3, Ч. 3. - С. 156-158.

12. Рябуха О. I. Ультраструктурні особливості синтетичної діяльності фолікулярних тироцитів при прийманні органічного йоду в умовах аліментарного йододефіциту / О. І. Рябуха // Вісник проблем біології і медицини. - 2017. - Вип. 4, Т. 2, № 140. — С. 134-139.

13. Славин М. Б. Методы системного анализа в медицинских исследованиях / М. Б. Славин. - М. : Медицина, 1989. - 302 с.

14. Сявавко М. Математичне моделювання за умов невизначеності / М. Сявавко, О. Рибицька. — Львів : Українські технології, 2000. — 319 с.

15. Murray J. D. Mathematical biology II: spatial models and biomedical applications (interdisciplinary applied mathematics) / J. D. Murray. - N. Y. : Springer, 2003. - 3rd ed. - Vol. 18. - 811 p.

16. Riabukha O. Application of new information technologies for the study of cell activity / O. Riabukha // The XI International Conference on Perspective Technologies and Methods in MEMS Design (MEMSTECH’ 2015) (2-6 September, 2015, Lviv — Polyana, Ukraine) [IEEE Cat. No. CFP1564A-PRT]. — 2015. — P. 69-71.

17. Waterman D. A. A guide to expert systems / D. A. Waterman. - N. Y. : Addison-Wesley, 1986. 419 p.

18. Zadeh L. A. The roles of fuzzy logic and soft computing in the conception, design and deployment of intelligent systems / L. A. Zadeh // BT Technology Journal. 1994. — Vol. 14, No. 4. - P. 32-36.

\section{References.}

1. Avtandilov, G. G. (2002). Osnovy kolichestvennoi patologicheskoi anatomii [Basis of quantitative pathological anatomy]. Moscow: AML.

2. Gubler, E. V., \& Genkin, A. A. (1973). Primenenie neparametricheskikh kriteriev statistiki v medikobiologicheskikh issledovaniyakh [Application of nonparametric statistical criteria in biomedical researches]. Leningrad: Meditsina (Medicine).

3. Vakulenko, D. V., Vakulenko, L. O., Kravets, N. O., Kutakova, O. V., Sverstyuk, A. S., \& Lesiv, V. V. (2017). Zastosuvannya korelyatsiinoho portretu v diferentsiinii diahnostitsi zakhvoryuvan' sertsevo-sudinnoi, legenevoi ta nervovoi sistem [Application of correlation portrait in the differential diagnosis of cardiovascular, pulmonary and nervous diseases]. Medichna informatika ta inzheneriya (Medical informatics and engineering), 2, 4-8. doi: org/10.11603/mie.1996-1960.2017.2.7888.

4. Lutsenko, M. T. (2011). Tsitofiziologiya [Cytophysiology]: a guide. Novosibirsk; Blagoveshchensk: SB RAMS.

5. Riabukha, O. I. (2000). Metod napivkil'kisnogo analizu elektronogram za Riabukhoyu O. I. [Method of semiquantitative analysis of electronograms according to Riabukha O. I.]: certificate of authorship SACRR of Ukraine PA No. 2769. (2000, February 16). Katalog derzhavnoi reestratsii (Catalog of state registration), 4, 11 .

6. Riabukha, O. I. (2003). Metod Riabukhi O. I. Viznachennya profiliv spetsial'nikh mozhlivostei gormonpoetichnikh klitin [Method by Riabukha O. I. for specifying the profiles of special capabilities of hormonopoietic cells]: certificate of authorship SIPS of Ukraine PA No. 7966. (2003, July 15). Avtors'ke pravo i sumizhni prava (Copyright and related rights), 4, 72.

7. Mintser, O. P., Voronenko, Yu. V., \& Vlasov, V. V. (2003). Obroblennya klinichnikh i eksperimental'nikh danikh u meditsini [Processing of clinical and experimental data in medicine]: textbook for students of higher education institutions. Kyiv: Vishcha shkola (High school).

8. Plashchevaya, E. V., Smirnov, V. A., Nigei, N. V., \& Lysak, V.A. (2014). Osnovnye vidy vrachebnoi logiki [The main types of medical logic]. In Posobie dlya prakticheskikh zanyatii po meditsinskoi informatike [Textbook for practical training in medical informatics] (p. 176). Blagoveshchensk: AGMA.

9. Rotshtein, A. P. (1996). Meditsinskaya diagnostika na nechetkoi logike [Medical diagnostics under fuzzy logic]. Vinnitsa: Kontinent-Prim.

10. Riabukha, O. I. (2017). Doslidzhennya sintetychnoi diyal'nosti folikulyarnikh tirotsitiv pry priimanni neorganichnogo iodu $\mathrm{v}$ umovakh alimentarnogo iododefitsitu [Study of the follicular thyrocytes' synthetic activity while taking inorganic iodine under conditions of alimentary iodine deficiency]. Visnik problem biologii i meditsini (Bulletin of problems 
in biology and medicine), 3(141), 218-223, doi: 10.29254/2077-4214-2017-4-3-141-218-223.

11. Riabukha, O. I. (2006). Ob’ektivizatsiya morfofunktsional'nogo stanu tirotsita shlyakhom viznachennya profiliv iogo spetsial'nikh mozhlivostei [Objectivization of morphofunctional conditions of the thyrocyt along the definition of structures of its special opportunities]. Tavricheskii medico-biologicheskii vestnik (Tavrichesky medico-biological bulletin), 9(3/3), 156-158.

12. Riabukha, O. I. (2017). Ul’trastrukturni osoblivosti sintetichnoi diyal'nosti folikulyarnikh tirotsitiv pri priimanni organichnogo iodu v umovakh alimentarnogo iododefitsitu [Ultrastructural features of the follicular thyrocytes' synthetic activity while taking organic iodine under conditions of alimentary iodine deficiency]. Visnik problem biologii i meditsini (Bulletin of problems in biology and medicine), 2(140), 134-139.

13. Slavin, M. B. (1989). Metody sistemnogo analiza $\mathrm{v}$ meditsinskikh issledovaniyakh [Methods of system analysis in medical researches]. Moscow: Meditsina (Medicine).

14. Syavavko, M., \& Ribits’ka, O. (2000). Matematichne modelyuvannya za umov neviznachenosti [Mathematical modeling in conditions of uncertainty]. L'viv: Ukrains'ki Tekhnologii (Ukrainian Technology).

15. Murray, J. D. (2003). Mathematical biology II: spatial models and biomedical applications (interdisciplinary applied mathematics). 3rd ed. Vol. 18. N. Y.: Springer.

16. Riabukha, O. (2015). Application of new information technologies for the study of cell activity. In The XI International Conference (MEMSTECH’2015) (2-6 September, 2015, Lviv — Polyana, Ukraine) [IEEE Cat. No. CFP1564A-PRT] (pp. 69-71).

17. Waterman, D. A. (1986). A guide to expert systems. N. Y.: Addison-Wesley.

18. Zadeh, L. A. (1994). The roles of fuzzy logic and soft computing in the conception, design and deployment of intelligent systems. BT Technology Journal, 14(4), 32-36. 